J. Asiat. Soc. Bangladesh, Sci. 39(1): 95-104, June 2013

\title{
MINERALOGICAL COMPOSITION OF SOILS FROM URIR CHAR - A TINY OFFSHORE ISLAND OF BANGLADESH
}

\author{
M.S. HUSSAIN, Z. H. KHAN ${ }^{1}$ AND M. IBRAHIM \\ Department of Soil, Water and Environment, University of Dhaka, Dhaka 1000
}

\begin{abstract}
Mineralogical composition of three surface soils from Urir Char - an environmentally vulnerable small offshore island of Bangladesh - was determined by X-ray diffraction analysis. In the bulk soils layer silicates and quartz were the dominant minerals while the quantity of feldspars was around ten percent. Quantity of weatherable minerals was very high in the soils. Illite was the dominant mineral in the clay fraction of the soils. The second dominant clay mineral was smectite which comprised around one-fourth of the clay fraction closely followed by chlorite with a small quantity of kaolinite mineral. Soil vermiculite and mixed layer minerals were absent in these soils. These soils had a mixed mineralogical composition with a high cation exchange capacity and percent base saturation. Texturally the soils were silty loam. Exchangeable $\mathrm{Ca}^{++} / \mathrm{Mg}^{++}$ratio was less than unity. Magnesium solonization was considered as the dominant pedogenic process along with gleization. There was problem of salinity as the elevation of land was around one meter above the mean sea level. Natural calamities like tropical cyclones and tidal surges were highly devastating as the island was completely washed with sea water.
\end{abstract}

Key words: Urir char, Offshore island, Clay mineralogy, Soil properties

\section{Introduction}

Urir Char is a small offshore island of Bangladesh located to the eastern side of the mouth of the Meghna estuary near the northern tip of the Bay of Bengal. This island was formed by the sediments derived from the Ganges-Brahmaputra-Meghna (GBM) river system. Urir char is divided into two parts - old charland which is protected by polders and is periodically flooded in the monsoon months by rain water. The other part is a freshly deposited new mud flat which is tidally affected. Bank erosion is little although the island is surrounded by water on all sides but the natural environment is quite fragile. The major natural calamites are devastating tropical cyclonic storms that come occasionally along with tidal surges.

Urir Char island is roughly an oval shaped land mass and lies between Sandwip upazila of Chittagong district and Companyganj upazila of Noakhali district (Fig. 1). Administratively, it is a union under Sandwip upazila of Chittagong district. This island is roughly $10 \mathrm{Km}$ long in the north-south direction and about $7 \mathrm{Km}$ wide in the east-west direction comprising an area of about 10000 ha of land and has a population of more than 9000 (Khan 2007). Because of the environmental vulnerability it is sparsely populated

\footnotetext{
${ }^{1}$ Corresponding author: E-mail: khnzh_du@yahoo.com
} 
and rice cultivation is the main occupation of the islanders with fishing and cattle/buffalo farming as secondary activities. More than $30 \%$ of the island has been brought under plantation mangrove forest under the coastal afforestation programme of Bangladesh Forest Department.

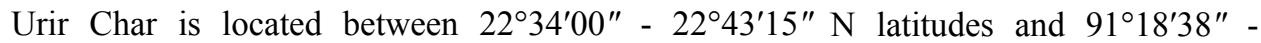
91 $24^{\prime} 43^{\prime \prime}$ E longitudes. Physiographically, it is an isolated coastal plain of Holocene period with an elevation of only 0.5-1.0 m above mean sea level (SRDI 1997). Agroecologically, this island has been designated as the Meghna Estuarine Charland (FAO-UNDP 1988). Soils of this island have developed on silts deposited by the Lower Meghna river, which is a mixture of the sediments derived from the GBM river system. The climate of the area is humid tropical monsoon with a mean annual rainfall of more than $3000 \mathrm{~mm}$ and over 90 percent of which falls during the months of March to October (SRDI 1997). Water supply from rainfall is enough to wash out salts from the soils. Strong tropical cyclones along with devastating tidal surges are the common natural hazards which lash the island occasionally. Rice is the principal crop grown in the island and Rabi/ fallow -Aus/fallow - transplanted Aman is the usual cropping pattern. Accretion and erosion occur along the sides of the island and new deposition of raw muds is vegetated with plantation mangrove forest at suitable time.

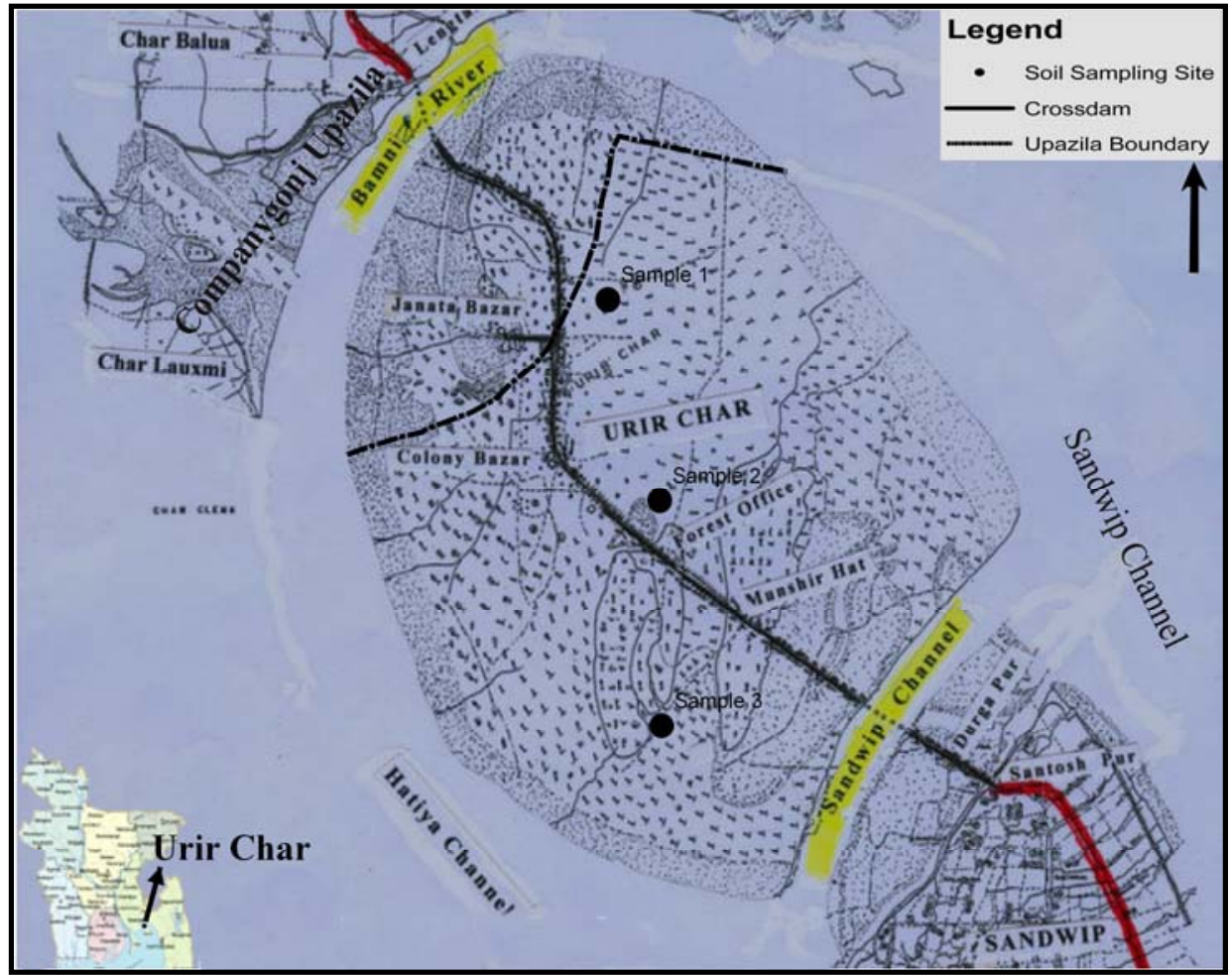

Fig. 1. Sketch map of Urir Char showing soil sampling site (source: modified from Khan 2007). 
The soils of Urir Char were surveyed by Soil Resources Development Institute and identified the soils as belonging to Ramgati series (SRDI 1997). Mineralogical investigation of soils is essential for characterizing the soils, as well as to ascertain the mineralogical impact on soil management and productivity and also to understand the nature of pedochemical weathering. The present paper attempts to report information on some basic soil properties and the bulk and clay mineralogical composition of some selected soils from Urir Char.

\section{Materials and Methods}

Three surface soil samples $(0-15 \mathrm{~cm}$ depth) from three selected locations of the oldest parts of the island, where rice cultivation is being practised, were collected for mineralogical investigations. The locations of the soil sampling sites have been recorded using a GPS and marked in a sketch map of Urir Char (Fig. 1). Soils in the older part of this island where cambic horizon have developed have been characterized as Inceptisols, mostly Endoaquepts (Soil Survey Staff 1999). The collected soil samples were physically and chemically analysed following standard methods and its results are presented in Table 1 . The mineralogical analysis of the soils was carried out in the laboratory of the Institute of Applied Geology, University of Natural Resources and Applied Life Sciences (BOKU), Vienna, Austria.

The mineralogical composition of bulk soil sample $(<2 \mathrm{~mm})$ as well as separated clay $(<$ $2 \mu \mathrm{m})$ fractions were determined. For bulk mineral analysis soil samples were prepared according to the "backload procedure" and analysed in a Philips X-ray-diffractometer (PW 1710, a long fine focus tube) with $\mathrm{Ni}$ filtered $\mathrm{Cu}-\mathrm{K} \alpha$ radiation $(45 \mathrm{kV}, 40 \mathrm{~mA})$ from $2^{\circ}$ to $70^{\circ} 2 \theta$. The measuring time was $1 \mathrm{sec}$. in step-scan mode with a step size of $0.02^{\circ}$. Semi -quantitative mineral composition of the soil samples was estimated using the method described by Schultz (1964). The clay mineralogical studies were performed by removing organic materials by oxidation with $\mathrm{H}_{2} \mathrm{O}_{2}$ (Kunze and Dixon 1986) and iron oxides by citrate - dithionite- bicarbonate method (Mehra and Jackson 1960). Clay fraction was separated by sedimentation method and the separated clay was saturated with $\mathrm{Mg}^{++}$and $\mathrm{K}^{+}$ions using $1 \mathrm{M} \mathrm{MgCl}_{2}$ and $\mathrm{KCl}$ solutions. The oriented clay samples on ceramic plates were scanned with a Philips $1710 \mathrm{X}$-ray diffractometer (XRD) with $\mathrm{Ni}$

filtered $\mathrm{Cu}-\mathrm{K} \alpha$ radiation (at $45 \mathrm{kV}, 40 \mathrm{~mA}$ ) at a scanning speed of $2^{\circ} 2 \theta$ per minute from $2^{\circ}$ to $40^{\circ} 2 \theta$. The identification of clay minerals was generally based on the methods outlined by Thorez (1975), Brindley and Brown (1980), Moore and Reynolds (1997) and Wilson (1989). Semi-quantitative estimations of minerals were carried out using the corrected intensities of characteristic X-ray peaks (Riedmüller 1978).

\section{Results and Discussion}

The soils of Urir Char are young, loamy textured with high percentage of silt and are alkaline in reaction with high cation exchange capacity (CEC). Percent base saturation of 
the soils is very high (Table 1). Exchangeable $\mathrm{Ca}^{++} / \mathrm{Mg}^{++}$ratio is less than unity. Karim and Bhuyian (1963) reported this kind of results in some soils from the coastal area of Chittagong and called the pedogenic process as magnesium solonization. The exchangeable $\mathrm{Na}^{+} / \mathrm{K}^{+}$ratio is near 3 which may be due to the fact that these soils are sometimes flooded by sea water. Exchangeable sodium percentage (ESP) in the soils is high but did not exceed 15 in any of the soils. The dominant soil forming processes are magnesium solonization along with gleization.

The semi-quantitative estimation of the minerals in the bulk soils indicates that the layer silicate minerals comprise the major portion (around 59\%) of the soils (Figs. 2 and 4). Quartz comprises about one third the bulk of which was present in the sand and silt

Table 1. Some physical and chemical properties of the soils from Urir Char.

\begin{tabular}{lccc}
\hline Properties & \multicolumn{3}{c}{ Results } \\
\cline { 2 - 4 } & Soil 1 & Soil 2 & Soil 3 \\
\hline GPS coordinates (Sampling & $22^{\circ} 41^{\prime} 21.408^{\prime \prime} \mathrm{N}$ & $22^{\circ} 39^{\prime} 07.777^{\prime \prime} \mathrm{N}$ & $22^{\circ} 37^{\prime} 05.709 " \mathrm{~N}$ \\
location) & $91^{\circ} 20^{\prime} 39.326^{\prime \prime} \mathrm{E}$ & $91^{\circ} 20^{\prime} 38.683^{\prime \prime} \mathrm{E}$ & $91^{\circ} 20^{\prime} 07.845^{\prime \prime} \mathrm{E}$ \\
$\mathrm{pH}\left(\mathrm{H}_{2} \mathrm{O}\right)$ & 7.6 & 7.7 & 7.5 \\
$\left.\mathrm{ECe}(\mathrm{dS} \mathrm{m})^{-1}\right)$ & 6.0 & 5.8 & 7.5 \\
Organic Carbon (\%) & 1.88 & 1.95 & 1.79 \\
Sand $(\%)$ & 22 & 19 & 20 \\
Silt $(\%)$ & 54 & 58 & 55 \\
Clay $(\%)$ & 24 & 23 & 25 \\
Textural Class & Silt loam & Silt loam & Silt loam \\
Exch. $\mathrm{Na}^{+}\left(\mathrm{cmol}^{+} \mathrm{kg}^{-1}\right)$ & 1.87 & 1.67 & 1.93 \\
Exch. $\mathrm{K}^{+}\left(\mathrm{cmol}^{+} \mathrm{kg}^{-1}\right)$ & 0.63 & 0.58 & 0.53 \\
Exch. $\mathrm{Ca}^{++}\left(\mathrm{cmol}^{+} \mathrm{kg}^{-1}\right)$ & 7.41 & 7.98 & 8.08 \\
Exch. $\mathrm{Mg}^{+}\left(\mathrm{cmol}^{+} \mathrm{kg}^{-1}\right)$ & 8.05 & 8.13 & 8.29 \\
Cation exchange capacity & 19.88 & 19.97 & 20.45 \\
(cmol $\left.^{+} \mathrm{kg}^{-1}\right)$ & & & \\
Base saturation percent & 90 & 92 & 92 \\
$(\mathrm{BSP})$ & & & \\
Exch. $\mathrm{Ca}^{++} / \mathrm{Mg}^{++}$ratio & 0.92 & 0.98 & 0.97 \\
Exch. $\mathrm{Na}^{+} / \mathrm{K}^{+}$ratio & 2.96 & 2.87 & 3.54 \\
Exchangeable sodium & 9.4 & 8.3 & 9.4 \\
percentage $(\mathrm{ESP})$ & & & \\
\hline
\end{tabular}

fractions. The $3^{\text {rd }}$ dominant mineral in the soil is feldspars ( $\mathrm{k}$-feldspar and plagioclase) which comprise on an average 12 percent. Plagioclase feldspars are much higher than Kfeldspars in all the studied soils (Figs. 2 and 4). Calcite mineral was not found in soils of Urir Char island although the sediments were derived from the Ganges, the Brahmaputra and the Meghna rivers together. The sediments of the Ganges river are known to be calcareous (Brammer 1996). The absence of calcite mineral in the sediments of Urir Char suggested that this mineral was probably depleted during transportation, sedimentation 
and diagenesis stages. Begum et al. (2004) studied the mineralogical composition of some soils from the Monpura island located in the lower Meghna estuary and reported that the layer silicate minerals comprise the major portion of these soils followed by quartz and feldspar. Huizing (1971) examined minerals in the sand fraction across the soils of the Bengal basin and reported that the floodplain soils were rich in feldspars, micas and amphiboles. These were mainly derived from crystalline rocks of the Himalayan mountain range.

One startling fact is that almost 70 percent of the minerals present in the soils are moderately to easily weatherable (Fig. 2). Occurrence of such a high quantity of weatherable minerals in these soils may indicate that they are chemically reactive and possess high nutrient reserve.

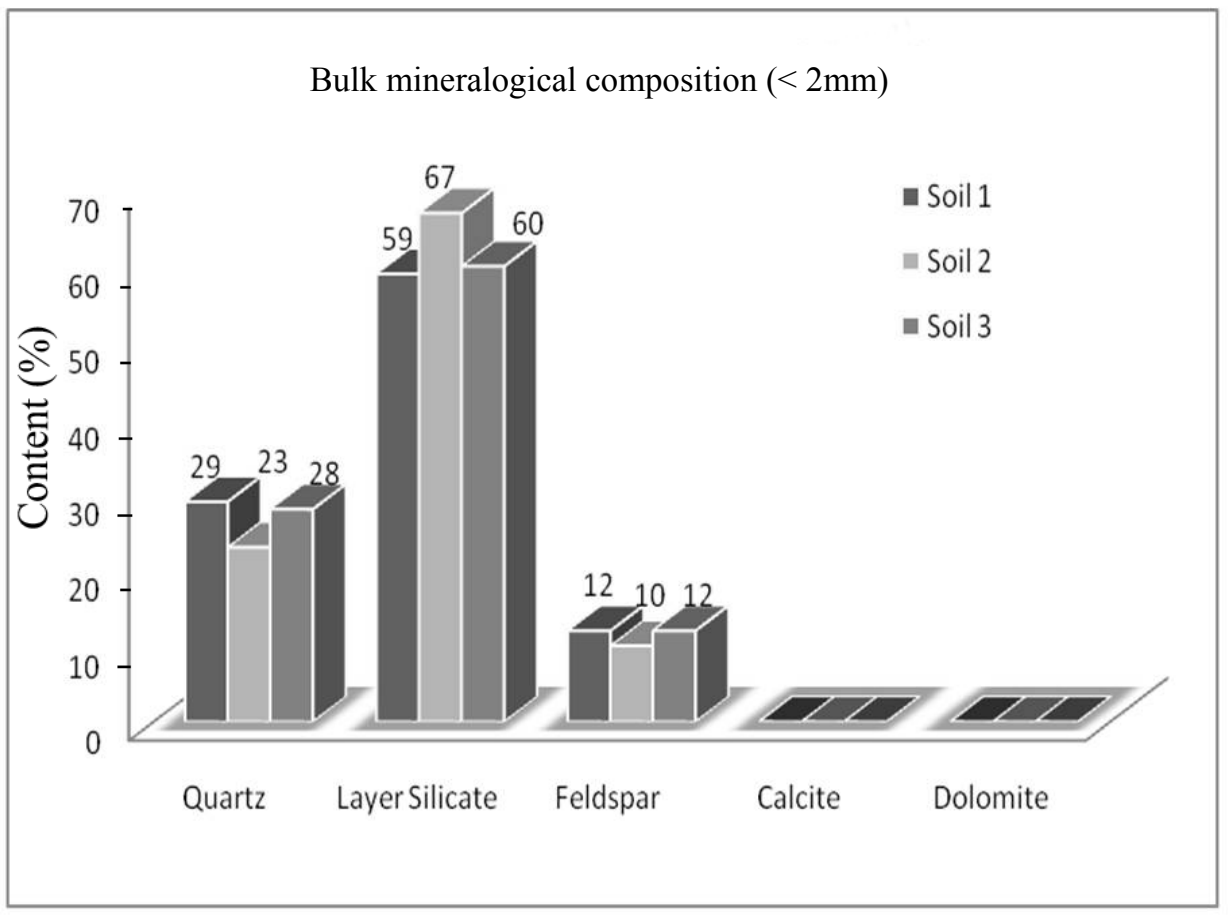

Fig. 2. Mineral composition of bulk soil samples from Urir Char. 


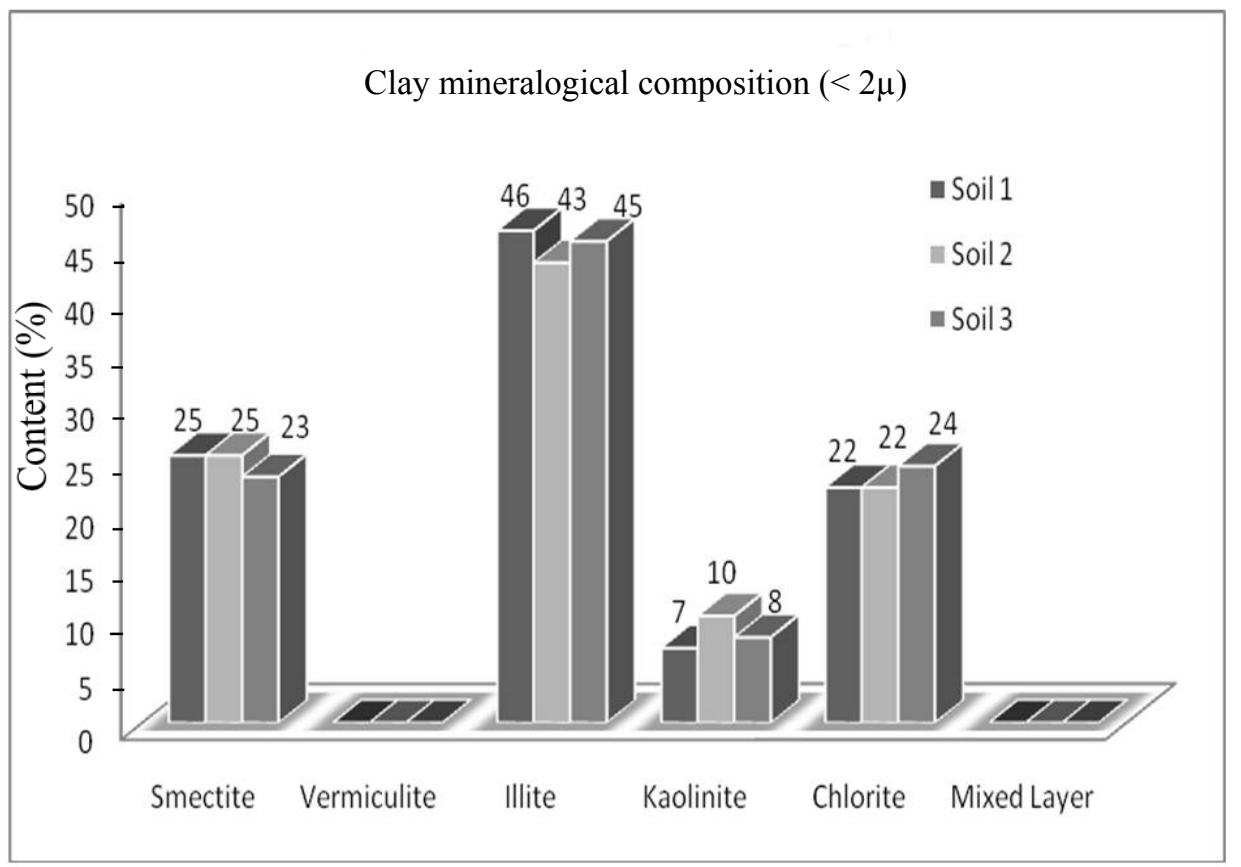

Fig.3. Mineral composition of clay fraction of surface soils from Urir Char.

The semi-quantitative estimation of clay minerals showed the dominance of illite in the clay fraction of the soils followed by smectite which comprised around one-fourth of the clay fraction (Figs. 3 and 5). Chlorite was the third dominant mineral in the clay fraction of the soils $(23 \%)$ with a small quantity (around $8 \%$ ) of kaolinite mineral. The absence of vermiculite in the clay fraction of the soil indicates that illite is not transforming to form expanding lattice minerals such as vermiculite. Almost one fifth of the clay fraction is occupied by chlorite which is thought to be derived from the parent material as an allogenic mineral and may remain unaffected by the present cycle of pedochemical weathering processes. Absence of interstratified minerals in the clay fraction is also interesting to note that mica is not being weathered to form expanding lattice minerals and that the minerals in the clay fraction were mostly inherited from the parent materials. It is possible that the soils of Urir Char were developed on sediments in which weathering processes have not advanced enough to significantly alter the silicate clay minerals. The presence of smectite mineral in the soils indicates that the soils were formed on alluvium derived from the combined sediments of the Ganges Brahmaputra and Meghna rivers. These results appears to be in conformity with the findings of White (1985) and Moslehuddin et al. (1998) in some GBM river floodplains soils of Bangladesh where they reported the occurrence of more than $20 \%$ smectite mineral in the clay fraction of the soils. 
The mineralogical composition indicates that the soil materials of the Urir Char island were mainly allogenic and their transformation process appears to be in the initial stage only. Occurrence of high quantity of weatherable minerals also indicates the occurrence of weak weathering and a considerably high nutrient reserve.

The clay mineral composition further indicates that the soils of Urir Char have a mixed mineralogy with significant quantity of smectite. With a mineralogical composition as this, the soils of Urir Char are expected to demonstrate a favourable physical as well as physicochemical condition for their agronomic use. Smectite mineral may have a high potassium fixing capacity. More $\mathrm{K}$ application may be recommended for enhancing the productivity of soils. The soils are medium textured and have an illite -smectite-chlorite clay mineralogical composition and consequently may be graded as having a 'good'

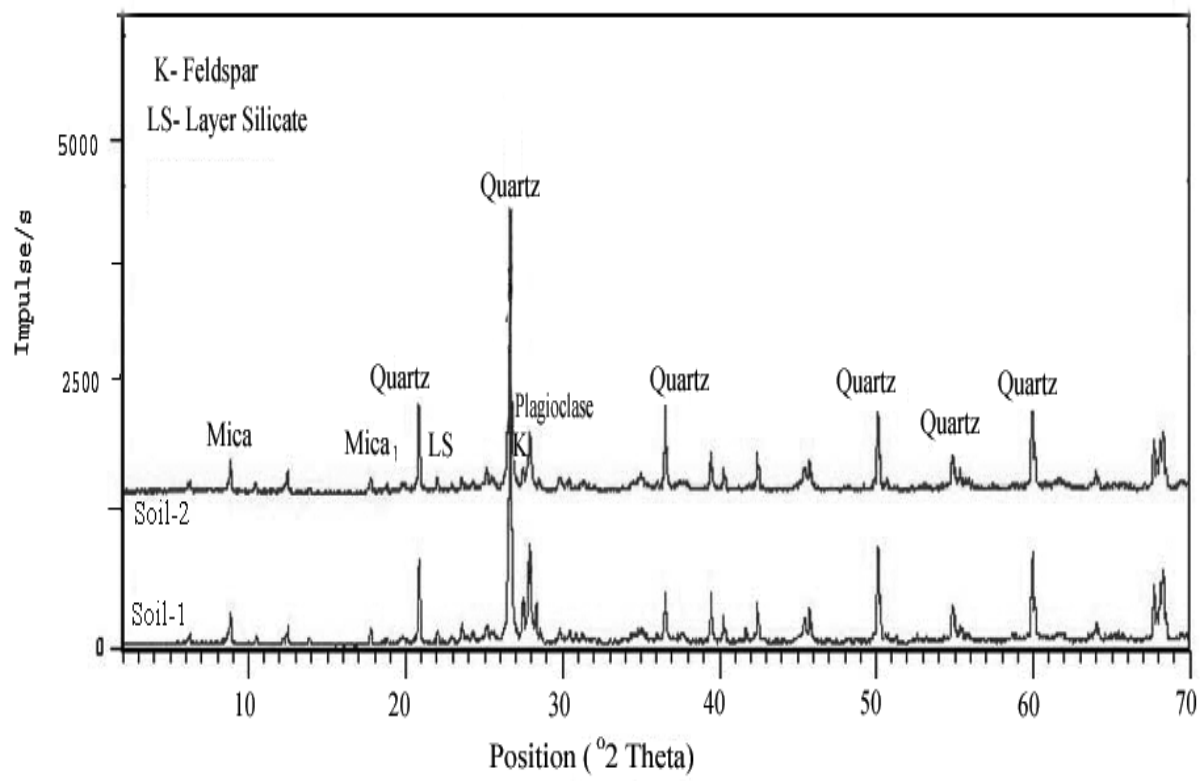

Fig. 4. X-ray diffractogram of bulk soil samples from Urir Char.

inherent potentiality which means good buffer capacity and good level of nutritional reserve. Therefore, these soils are easy to manage and are expected to support good crop growth and high production. Egashira and Yasmin (1990) also evaluated the inherent potentiality of some floodplain soils on the basis of their type and amount of clay minerals and noted that the soils having silt loam texture and high quantity of illite and smectite minerals could be rated as having a 'good' inherent potentiality. Hussain (1998) reported that clay mineralogical compositions in Bangladesh soils have little adverse effect on their management properties. According to him, mixed mineralogy is a boon 
and this mineralogy class is the most ubiquitous and, by far, cover the largest area of agricultural land in this country. Quantity of minerals having extreme physical properties such as high COLE (coefficient of linear extensibility) is quite small in this country. It is clear from the present study that the soils have few limitations from their mineralogical aspect.

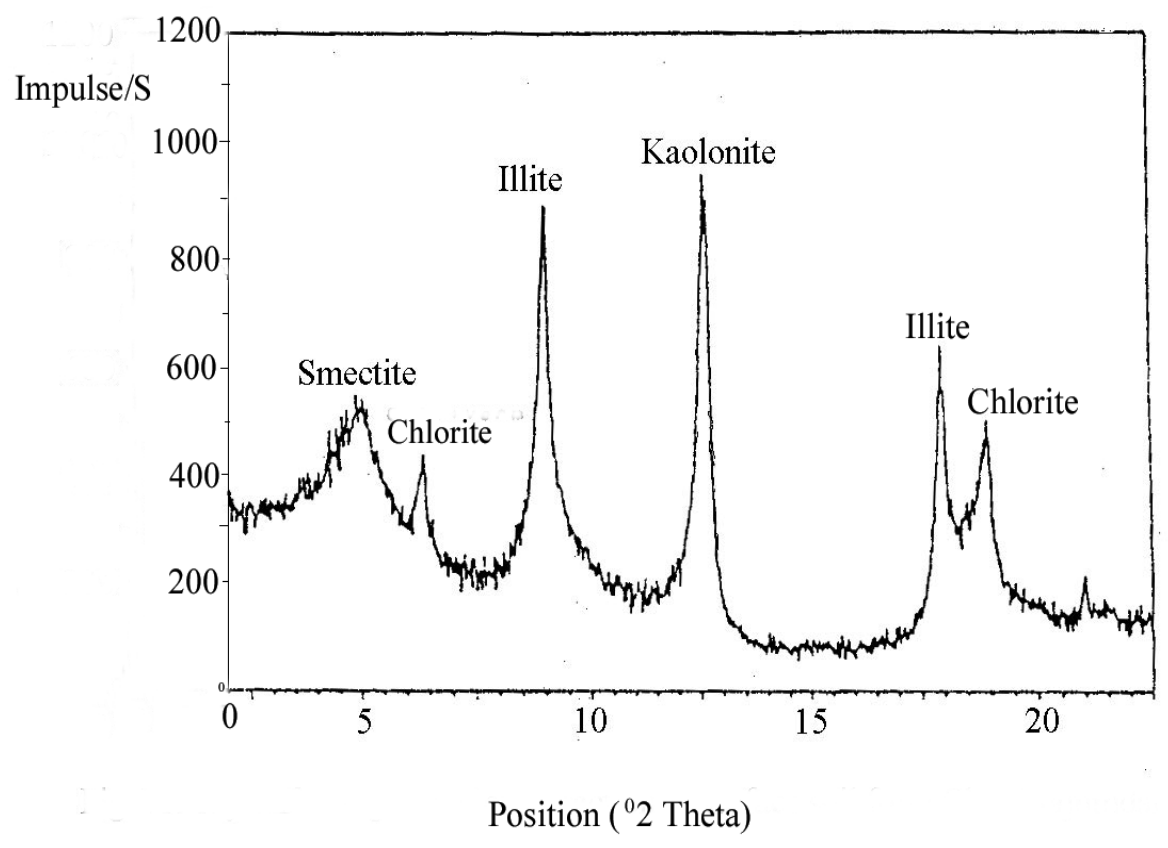

Fig. 5. X-ray diffractogram of clay fraction of a surface soil from Urir Char.

Each person in Urir Char has more agricultural land in his share in comparison to that in the mainland Bangladesh, but there are some serious natural limitations such as low elevation from the sea level and the seasonal occurrences of tropical cyclones. In reality Urir Char has fragile swampy land with some hazards and human habitation there should be discouraged and restricted.

Perhaps, it will not be quite irrelevant to put a note of warning that plans are in place to increase the area of Urir Char by building cross dams (Khan 2007). The adverse impacts of this cross damming system on the nearby lands and islands have not been examined closely and sufficiently. The presently severe and unstoppable erosion along the eastern bank of Bhola may possibly be distantly related to these cross dams, as river morphology is not seriously and efficiently studied in this country of rivers by experts. 


\section{Acknowledgement}

The authors are grateful to Univ. Prof. Dr. Franz Ottner, University of Natural Resources and Applied Life Sciences (BOKU), Vienna, Austria for his help in X-ray diffraction analysis.

\section{References}

Begum, A., M.S. Hussain, S.M. Ullah and F. Ottner. 2004. Morphological and mineralogical features of some soils from the Manpura island of Bangladesh. J. Asiatic Soc. Bangladesh Sci. 30(1):17-28.

Brammer, H. 1996. The Geography of the Soils of Bangladesh. The University Press Limited, Dhaka, Bangladesh. pp. 287.

Brindley, G. W. and G. Brown. 1980. Crystal Structures of Clay Minerals and their X-Ray Identification. - Mineralogical Society, London. pp. 495.

Egashira, K and M. Yasmin. 1990. Clay mineralogical composition of floodplain soils of Bangladesh in relation to physiographic units. Bull. Inst. Trop. Agr. Kyushu Univ. 13:105- 126.

FAO-UNDP. 1988. Land Resources Appraisal of Bangladesh for Agricultural Development. Report 2 and 3. Agroecological regions of Bangladesh. FAO, Rome. 570 pp.

Huizing, H.G.J. 1971. A reconnaissance study of the mineralogy of sand fractions from East Pakistan sediments and soils. Geoderma. 6: 109-133.

Hussain, M.S. 1998. Management implications of soil mineralogy in Bangladesh. Paper no. 2321. $16^{\text {th }}$ ISSS Int. Cong. Proc., Montpellier, France. 1280 pp.

Karim, A and Z.H. Bhuiyan. 1963. A pedogenic study of the magnesium solonetz soils of Chittagong. Proc. $15^{\text {th }}$ Pakistan Sci. Conf. C-29 (Agri and Forestry Section).1-10 pp.

Khan, S.R. 2007. The Sandwip-Urir Char- Noakhali cross dam: One of the definite means for survival and improvement in quality of lives of lac of people of Bangladesh. Bangladesh Water Development Board, Dhaka. pp.1-12.

Kunze, G.W. and J.B. Dixon. 1986. Pretreatment for mineralogical analysis. In: A. Klute (ed.). Methods of Soil Analysis. Part 1. AmericanSociety of Agronomy, Madison, Wisconsin. 90-100 pp.

Mehra, O. P. and M. L. Jackson. 1960. Iron oxide removal from soils and clays in a dithionitecitrate-bicarbonate system buffered with sodium bicarbonate. Clays Clay Miner. 7: $317-$ 327.

Moore, D.M. and R. C. Jr. Reynolds. 1997. X-Ray Diffraction and the Identification and Analysis of Clay Minerals. - Oxford Univ. Press, New York. 378 pp.

Moslehuddin, A.Z.M., S.M. Saheed and K. Egashira. 1998. Mineralogical approach to alternation of different river sediments in Meghna floodplain soils of Bangladesh. Clay Sci. 10: 375384.

Riedmüller, G. 1978. Neoformations and Transformations of Clay Minerals in Tectonic Shear Zones. - TMPM Tschermaks Min. Petr. Mitt. 25: 219-242.

Schultz, L. G. 1964. Quantitative Interpretation of Mineralogical Composition from X-Ray and Chemical Data of the Pierre Shales. - Geol. Surv. Prof. Paper, $\underline{391 C,} 10$ Abb., 8 Tab., Washington, D.C. 1-31 pp.

Soil Survey. 1999. Soil Taxonomy-A Basic System of Soil Classification for Making and Interpreting Soil Surveys. $2^{\text {nd }}$ ed. Agric. Handb. No. 436. US Govt. Printing Office, Washington, D.C. 867 pp. 
SRDI. 1997. Upazila Nirdeshika of Sandwip. Soil Resource Development Institute (SRDI). Farmgate, Dhaka. 77pp.

Thorez, J. 1975. Phyllosilicates and Clay Minerals - a laboratory handbook for their x-ray diffraction analysis. - Editions G. Lelotte, 579 S., Liege. 579 pp.

White, J.L. 1985 Summary of results of mineralogical study of clay fractions of Bangladesh soils. In: Proceedings of the Workshop on Soil Clay Mineralogy. Bangladesh Agricultural Research Council, Dhaka, Bangladesh. pp1-68.

Wilson, M.J. 1989. A Handbook of Determinative Methods in Clay Mineralogy. - Verlag Blackie, Glasgow and London. 308 pp.

(Received revised manuscript on 15 April 2013) 